\section{REDISCOVERY OF THE EMPRESS, SASAKIA FUNEBRIS LEECH (LEPIDOPTERA: NYMPHALIDAE: NYMPHALINAE: APATURINI) AFTER 88 YEARS IN INDIA}

\section{Arun P. Singh}

Ecology \& Biodiversity Conservation Division, Rain Forest Research Institute, Jorhat, Assam, India

singhap@icfe.org, ranoteaps@gmail.com

The Empress, Sasakia funebris (Leech, 1891) is reported to be 'very rare' in India (Evans 1932; WynterBlyth 1957) and is also listed as a protected species in Schedule I of the Indian Wildlife (Protection) Act, 1972 (Anonymous 1997). The species is included as 'Critically Endangered' in the 'Red Data Book' of Indian Butterflies (Gupta \& Mondal 2005) but the taxon has not yet been assessed for the IUCN Redlist (IUCN 2012). The habits and ecology of this species in India are not well known. The species is distinct in appearance with the male having the ground colour black. Its forewing cell has a narrow basal red streak above, which is much wider on the underside, and the hindwing underside has red basal markings. Both wings have the outer halves prominently streaked with dirty white longitudinal V-shaped stripes. The female is similar to the male. Wing expanse: 125$130 \mathrm{~mm}$ (Evans 1932).

Four specimens of this species were collected at Yakama (=Jakhama), Naga Hills (Nagaland) at $1520 \mathrm{~m}$ in July in 1911 and 1912 (Tytler 1915). One male was later collected by O.C. Ollenbach from Jakhama in Naga Hills at 1800 m on 25 June 1924, which is preserved in the National Forest Insect Reference Collection (NFRIC) at the Forest Research Institute, Dehradun. There are no other published records of this species from Naga Hills thereafter, and its occurrence in India has been reported as doubtful as surveys in Sikkim, eastern Arunachal Pradesh, Assam, Nagaland, Manipur, Meghalaya and Myanmar have

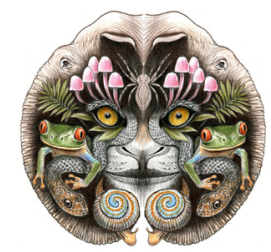

ISSN

Online 0974-7907 Print 0974-7893

\section{OPEN ACCESS} failed to record this species (Tytler 1940; Varshney \& Shukla 1988; Haribal 1992; Kinyon 2004; Borang et al. 2008; Singh et al. 2011; Gogoi 2012, 2013; Kunte et al. 2012; Sondhi et al. 2013).

The distribution of this species extends from northeastern India through China to Taiwan. S. funebris occurs as three sub-species. The subspecies S.f. funebris Leech known from Naga Hills in India also occurs in western China, S.f. genestieri Oberthür occurs in Yunnan Province in China and S.f. fuluralis Matsumura is found in Taiwan. The species has been bred on Celtis sinensis in Yunnan, China.

Discussion: During the course of a survey on 'Reassessment of forest types of India', in Upper Debang Valley District of Arunachal Pradesh this species was incidentally photographed on the road side and later identified. The details of this record are presented below (Table 1), along with the images (Image $1 \mathrm{a \& b}$ ).

At the site where this species was observed, biotic interferences were low although threats to the forests in the area include shifting cultivation, grazing, fuel wood and timber extraction on a minor scale.

The present record extends the known Indian distribution of the species to Arunachal Pradesh (eastern Himalaya) from its previously reported range in the Naga Hills (Evans 1932), a different hill range and this record is more than $200 \mathrm{~km}$ away from pervious records.

DOI: http://dx.doi.org/10.11609/JoTT.o3428.4514-6 | ZooBank: urn:Isid:zoobank.org:pub:83EAB156-C27B-486E-A4D1-59D49F9C1342

Editor: Peter Smetacek, Nature research \& adventure in the Himalaya, Nainital, India.

Date of publication: 26 June 2013 (online \& print)

Manuscript details: Ms \# 03428 | Received 08 December 2012 | Final received 01 June 2013 | Finally accepted 02 June 2013

Citation: Singh, A.P. (2013). Rediscovery of the Empress, Sasakia funebris Leech (Lepidoptera: Nymphalidae: Nymphalinae: Apaturini) after 88 years in India. Journal of Threatened Taxa 5(10): 4514-4516; http://dx.doi.org/10.11609/JoTT.03428.4514-6

Copyright: (C) Singh 2013. Creative Commons Attribution 3.0 Unported License. JoTT allows unrestricted use of this article in any medium, reproduction and distribution by providing adequate credit to the authors and the source of publication.

Funding: Indian Council of Forestry Research \& Education (ICFRE), Dehradun

Competing Interest: None.

Acknowledgements: The author is thankful to Dr. H.B. Naithani for identification of plants. Thanks are due to DG, ICFRE and Director, RFRI for providing the necessary facilities. Support of the PCCF and Chief Wildlife Warden of Arunachal Pradesh State Forest Department is duly acknowledged. 

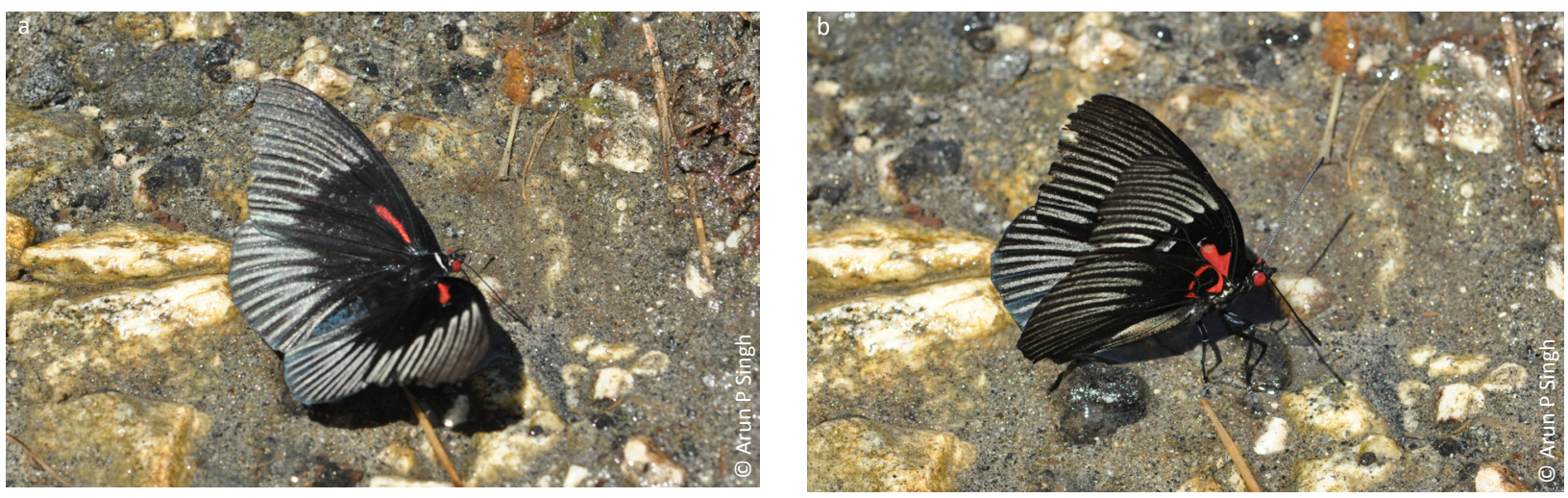

Image 1 a\&b. Dorsal and ventral view of Empress Sasakia funebris recorded near Anini, Upper Debang Valley District, Arunachal Pradesh.

Table 1. Location and details of the habitat where currently sighted and habits of the species

\begin{tabular}{|c|c|}
\hline Parameters & Site Details \\
\hline Location \& Coordinates & On Anini-Mippi Road, Debang Valley District, Arunachal Pradesh, $28^{\circ} 49^{\prime} 24^{\prime \prime} \mathrm{N} \& 9^{\circ} 52^{\prime} 59^{\prime \prime} \mathrm{E}$ (Image 2) \\
\hline Altitude, aspect, slope & 1657m; South-west; hilly $65^{\circ}$; Roadside \\
\hline Time of the day & 11:07hr; 13 August 2012; Sunny \\
\hline Habitat & Mixed sub-tropical broadleaf forest (Image 3) \\
\hline Dominating tree species & Castanopsis sp., Quercus sp., Rhus succeliana. \\
\hline Other vegetation & $\begin{array}{l}\text { Bamboo Phyllostychus manaii (along the road side near by); Exbucklandia populena, Cinamomum sp., Symplocos } \\
\text { sp., Rubus ellipticus, Hedychium sp., ferns, etc. }\end{array}$ \\
\hline Habit & $\begin{array}{l}\text { This individual preferred to remain in cover but came down to an eroded mud patch along the road to drink during } \\
\text { bright sunshine for a minute or so before disappearing again into thick cover above. Subsequent efforts to spot the } \\
\text { butterfly from 11:07-11:30 hr and then again from 15:30-16:30 hr, the same day at the same spot, failed. }\end{array}$ \\
\hline Morphology & $\begin{array}{l}\text { The individual photographed has all the morphological features similar to the specimen kept in NFIRC, Dehradun } \\
\text { and as per literature. The colour of the eyes is red as photographed. }\end{array}$ \\
\hline $\begin{array}{l}\text { Other species sharing the } \\
\text { same habitat }\end{array}$ & $\begin{array}{l}\text { Manipur Jungle Queen Sticopthalma sparta ( } 5 \text { no.); Northern Jungle Queen S.camadeva (4 no.); Popinjay Stibochiona } \\
\text { nicea ( } 2 \text { no.); Green Duke, Euthalia sahadeva ( } 2 \text { no.). }\end{array}$ \\
\hline
\end{tabular}

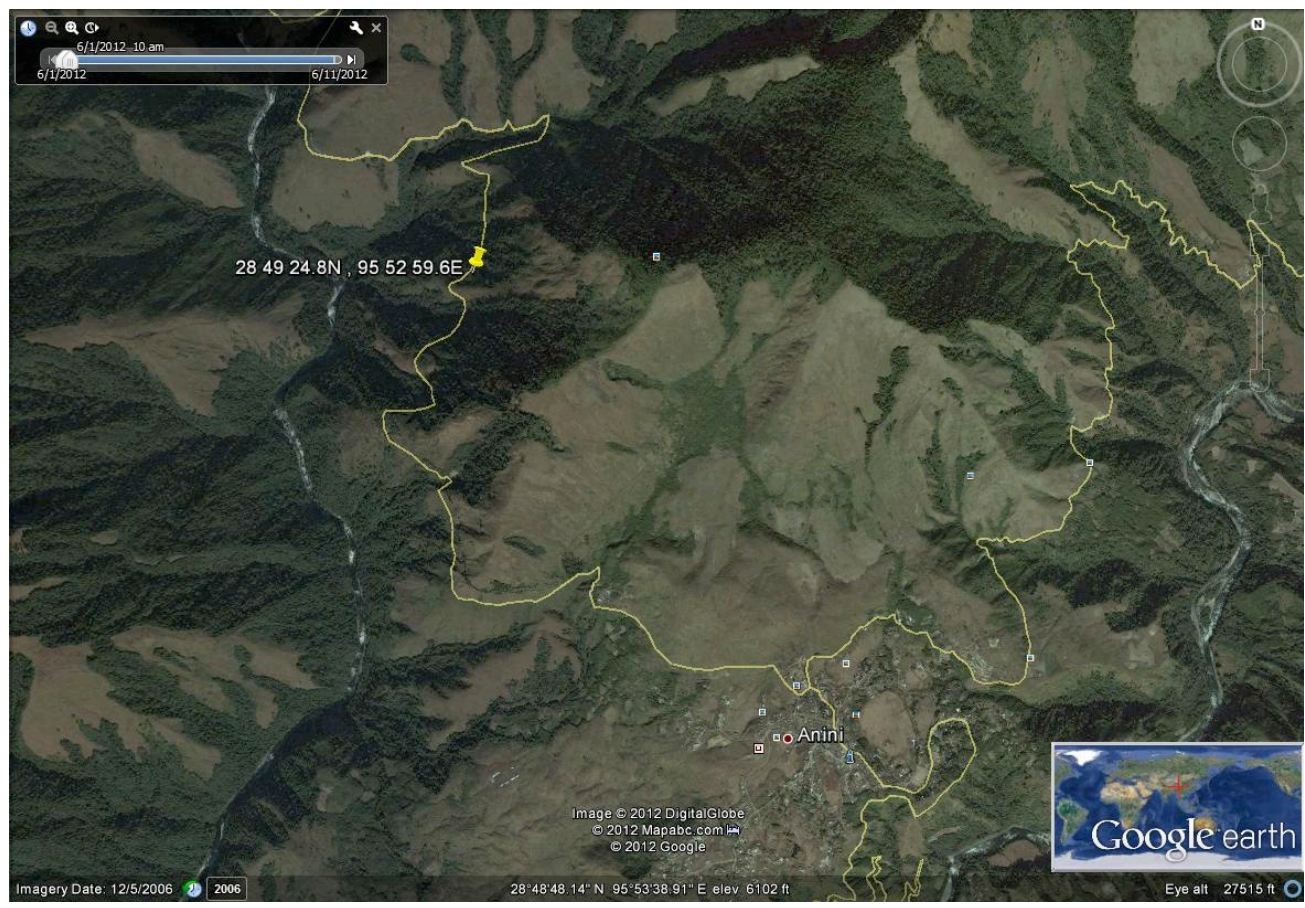

Image 2. Location of the site of present record of the Empress, Sasakia funebris near Anini, Upper Debang Valley District, Arunachal Pradesh. 


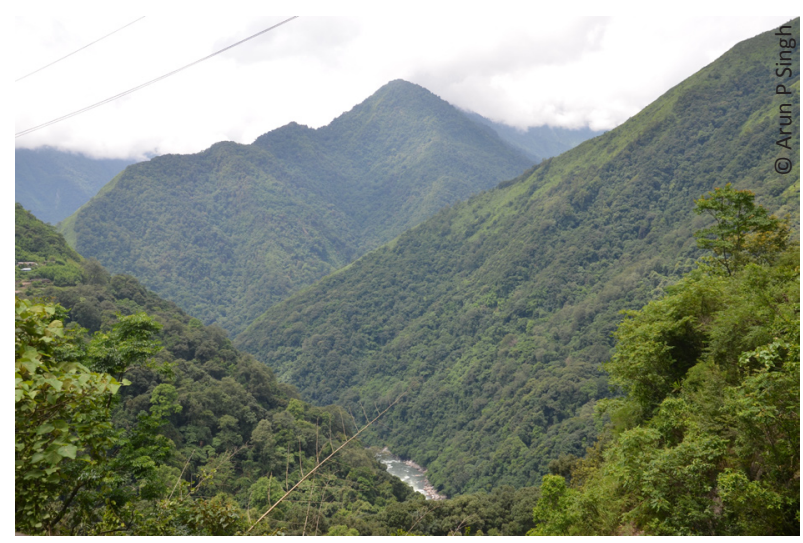

Image 3. Mixed sub-tropical broad-leaf forest around the site where the Empress Sasakia funebris was recorded.

\section{REFERENCES}

Anonymous (1997). The Wildlife (Protection) Act, 1972 (as amended up to 1993). $4^{\text {th }}$ Updated Edition. Natraj Publishers, Dehra Dun, $158 \mathrm{pp}$.

Borang, A., B.B. Bhatt, M. Tamuk, A. Borkotoki \& J. Kalita (2008). Butterflies of Dihang Dibang Biosphere Reserve of Arunachal Pradesh, eastern Himalayas, India. Bulletin of Arunachal Forest Research 24(1\&2): 41-53.

Evans, W.H. (1932). The Identification of Indian Butterflies - 2nd Edition. Bombay Natural History Society, Mumbai, India, 464pp+32pl.

Gogoi, M.J. (2012). Butterflies (Lepidoptera) of Dibang Valley, Mishmi Hills, Arunachal Pradesh, India. Journal of Threatened Taxa 4(12): 3137-3160; http://dx.doi.org/10.11609/JoTT.o2975.3137-60

Gogoi, M.J. (2013). A preliminary checklist of butterflies recorded from Jeypore-Dehing forest, eastern Assam, India. Journal of Threatened Taxa 5(2): 3684-3696; http://dx.doi.org/10.11609/ JoTT.03022.3684-96
Gupta, I.J. \& D.K. Mondal. (2005). Red Data Book (Part-2) - Butterflies of India. Zoological Survey of India, Kolkata, 535pp.

Haribal, M. (1992). The Butterflies of Sikkim Himalaya and their natural History. Sikkim Nature Conservation Foundation, Gangtok, Sikkim, 217pp.

IUCN (2012). IUCN Red List of Threatened Species. Version 2012.2. <www.iucnredlist.org>. Downloaded on 07 March 2013.

Kinyon, S. (2004). A Field Guide to the Butterflies of Myanmar. National Wildlife Conservation Department, Smithsonian Institution, 197pp.

Kunte, K., S. Sondhi, B.M. Sangma, R. Lovalekar, K. Tokekar \& G. Agavekar (2012). Butterflies of the Garo Hills of Meghalaya, northeastern India: their diversity and conservation. Journal of Threatened Taxa 4(10): 2933-2992; http://dx.doi.org/10.11609/ JoTT.02945.2933-92

Leech, J.H. (1891). New Species of Lepidoptera from China. Entomologist 24(Supplement): 23-31.

Singh, I.M., A. Gupta \& R. Varatharajan (2011). Butterfly fauna of Keibul Lamjao National Park, Manipur, North East India. Current Science 101(6): 719-721.

Sondhi, S., K. Kunte, G. Agavekar, R. Lovalekar \& K. Tokekar (2013). Butterflies of the Garo Hills. Samrakshan Trust (New Delhi), Title Trust (Dehradun), and Indian Foundation for Butterflies (Bengaluru), xvi+200pp.

Tytler, H.C. (1915). Notes on some new and interesting butterflies from Manipur and Naga Hills. 1 Journal of the Bombay Natural History Society 23: 502-515+4pls.

Tytler, H.C. (1940). Notes on some new and interesting butterflies chiefly from Burma - 1 \& 2. Journal of the Bombay Natural History Society 41(2): 235-252, 42(1): 109-123.

Wynter-Blyth, M.A. (1957). Butterflies of the Indian Region. Bombay Natural History Society, Bombay, $x x+523 p p+72 p l$.

Varshney, R.K. \& J.P.N. Shukla (1988). Studies on the Butterflies of Arunachal Pradesh and adjoining areas (Lepidoptera: Acraeidae, Satyridae, Nymphalidae, Riodinidae and Lycaenidae). Records of Zoological Survey of India, Occasional Paper 109: 117pp+23pls. 